\title{
The Effect of Perception of Utilization, Perception of Easy of Use and Taxpayer Satisfaction on E-Filing Use by Tax Payer
}

\author{
Nurul Mahmudah*, Ely Kartikaningdyah \\ Managerial Accounting Department \\ Politeknik Negeri Batam \\ Batam, Indonesia \\ *nmahmudah_89@yahoo.com
}

\begin{abstract}
This study aims to determine whether or not the influence of perceptions of usefulness, convenience perceptions, and user satisfaction with the use of e-filing. The data of this study were obtained from the questionnaire (Primer) distributed to taxpayers in Batam, especially in the Telecommunications Company with a sample of 50 respondents. The results showed that (1) the perception of usefulness had positive effect on the use of e-filing. This is evidenced by a simple linear regression analysis obtained from the sig value. 0.003 Which can be interpreted that the result value sig. $<0,05$ which means there is influence between usability perception toward usage of e-filing. (2) The perception of ease of use has a positive effect on the use of e-filing. This is proved by simple linear regression analysis obtained by sig value. 0,023 which can be interpreted that result of sig value. $<0.05$ which means there is an influence between the perception of ease of use towards the use of e-filing. (3) User satisfaction has no effect on the use of e-filing. This is proved by simple linear regression analysis obtained by sig value. 0,761 which can be interpreted that result of sig value. $>0.05$ which means there is no influence between user satisfactions with the use of e-filing. (4) Perceptions of usability, perceptions of ease of use and user satisfaction together influential. This is evidenced by simple linear regression analysis obtained by sig. 0.018. From these results can be concluded that the perception of usability, perceived ease of use affect the use of e-filing while user satisfaction does not affect the use of e-filing. This research still has limitation that sampling only focuses on Telecommunication Company only, it is recommended for further research in order to add variable and sample to be studied.
\end{abstract}

Keywords-participatory budgeting, budget goal clarity, internal control, managerial performance, financial accountability

\section{INTRODUCTION}

Tax online system has received great attention globally through the development of information technology which affect the tax administration system. The rise of tax administrator's information technology is to improve the tax administration system by creating awareness about their tax structure because most taxpayers have limited knowledge of tax administration system [1]. Information technology makes simple services offered to citizens [2]. The use of information technology has provided a new perspective for the development and integration of tax administration system.

Modern administration by utilizing information technology was introduced as an answer to the complaints against tax administration which is considered to be a weakness and irregularities in the field of taxation. To provide better service and supervision required adequate information technology, Tax Information System (SIP) used since 1994 is not sufficient to serve and oversee taxpayers throughout Indonesia. In 2002, SIP was developed into an Integrated Tax Administration System (SPAT) based on organizational structure based on function, because there is still a weakness in the taxpayer reporting system (WP) that is still using manual reporting, then the fiscal party requires double work by doing the recording is prone to human error (human error) and requires human resources that are not small, by reason of the Directorate General of Taxes developed several programs aimed at improving services to taxpayers in the form of e-filing.

E-filing is a way of delivering the annual income tax returns electronically are done online and in real time via the internet on the page (website) DGT Online (https://djponline.pajak.go.id) or electronic tax return service provider home page. E-Filing is one of the important government services in developing countries, as it allows taxpayers to make it easier to pay their taxes. E-filing offers comfort for the taxpayer that is the time to ask, where filings, ease of use, search for information and transactions online. Efiling also offers the flexibility of time and minimize errors in the calculation of tax.

This study took a sample of the individual taxpayer in the Telecommunication Company in Batam, because Taxpayers who use e-Filing in the company is still relatively small. In the Telecommunication Company in Batam on average only half of the employees who use the e-filing system. Socialization of the e-filing is also still very low for these companies. Furthermore, to find e-filing policy in the reporting of the company's Annual SPT Telecom. 
The purpose of this study were:

- To know there is or not the influence the perception of the usefulness of the use of e-Filing by the taxpayer,

- To know there is or not the influence the perceived ease of the use of e-Filing by the taxpayer,

- To know there is or the influence user satisfaction towards the use of e-Filing by the taxpayer,

- To determine whether or not there is a perception influences usefulness, perceived ease of use and satisfaction of taxpayer jointly on the use of e-Filing by taxpayers.

\section{LITERATURE REVIEW}

Analysis of the quality of services or Service Quality is a descriptive method to describe the level of customer satisfaction. This method was developed by Parasuraman Service Quality (quality of service) is a measure of how well a service encounter compatibility with customer expectations [3]. Conducting service quality means compromising with customer expectations in a consistent manner.

Customer satisfaction theory. According to Sugiyono customer satisfaction is a customer response to a perceptual evaluation of the difference between initial expectations before purchase (or other performance standards) and the actual performance of the product as perceived after consuming or consuming the product $[4,5]$. Customer satisfaction is not an absolute concept, but rather relative to what customers expect. Operationalization of customer satisfaction measurement can use a number of factors, such as expectations, level (importance), performance, and ideal factor [4]. E-filing is a way of delivering tax return or delivery of SPT Annual Renewal Notice electronically conducted online real time via the website of the Directorate General of Taxes (www.pajak.go.id) or Application Service Provider or Application Service Provider (ASP).

In general, the submission of tax return or delivery Renewal Annual Tax Return electronically through E-filing is regulated through DGT Regulation number PER-48 /PJ/2011 regarding the Second Amendment DGT Regulation number. PER19/PJ/2009 on Procedures Acceptance and Processing Notice of Annual December 30, 2011. in particular, the submission of tax return or delivery Renewal Annual Tax Return electronically through E-filing on the site Directorate General of Taxation is regulated through DGT Regulation number PER-39/PJ/2011 on Procedures Submission of the Annual Tax For Individual Taxpayer Using the Form 1770s or 1770SS In E-filing Through Website Directorate General of Taxes (www.pajak.go.id) dated December 23, 2011.

The Directorate General of Taxation has issued a regulation on e-filing is that the Regulation Directorate General of Taxation Number PER47/PJ/2008 on Procedures for Delivery Notification and Delivery Notification Extension Annual Tax Return in Electronic (e-filing) through an Application Service Provider (ASP). Taxpayers no longer need to come to the Tax Office if you already use e-filing facility so that the delivery of SPT to more easily and quickly. This is because the SPT data transmission can be done anywhere and anytime, and sent directly to the database of the Directorate General of Taxation with internet facilities are routed through one or more enterprise Application Service Provider appointed by the Directorate General of Taxation. E-filing facilitate the delivery of SPT and provide assurance to taxpayers that it is perfectly acceptable SPT Directorate General of Taxation and security is much more secure.

Research by Mustapha, discusses the tax service quality and perceived ease of use of online tax system [6]. The result of this study is that there is a positive relationship between the quality of tax service and the perception of ease of use, there is a positive relationship between the ease of use perspective and the use of online tax system, there is a positive relationship between the quality of tax services and the use of online tax system, there is a significant mediation effect Perceived ease of use between the use of online tax systems and the quality of tax services. The result of the whole states the whole hypothesis is significant.

The equation of this study lies in the perceived ease of use of online tax system. The difference lies in the variables used are the quality of tax service and online tax system, whereas in this study the variables used are the usability, user satisfaction, and system usage.

Research Situmorang, the perception of the usefulness of having a positive relationship with the use of e-filing [7]. The perception of the ease of having a positive relationship with the use of e-filing. Perception of satisfaction has a positive relationship with the use of e-filing. Perception complexity has a negative correlation with the use of e-filing. Perception of risk has a negative correlation with the use of e-filing. Research Liang, the results of study is self-efficacy has a significant influence on the perceived attributes of relative advantage, compatibility and complexity [8]. Social norms have a significant effect on trial ability (possibly attempted) and observability (possibly observed). Self-efficacy had no significant effect on the intention of use. The perceived attributes of relative advantage, compatibility, and complexity have a significant effect on the intent of use. Perceived attributes of trial ability and observability no significant effect on the intention of use. Social norms have a significant effect on usage intent.

\section{A. Hypothesis}

Perception of usefulness is a level where a person believes that the use of a system will be able to improve performance, increase the level of productivity and effectiveness. In the organizational context, this perception of usefulness is linked to improvements in individual performance that impact on opportunities to gain both material and non-material benefits. In the context of the use of e-filing can be interpreted that the use of e-filing can improve performance for taxpayers who use them. Someone will use e-filing if the person believes that efiling can provide benefits in carrying out his duties. Research Chin, level of perception affects the usefulness of e-filing taxpayers to use the e-filing [9]. Based on the results of the research above this research takes the hypothesis: 
- H1: There is a positive influence on the perception of usefulness in the use of e-filing.

Ease of meaning without difficulty or freedom from difficulty or unnecessary effort. Thus, the perception of ease of use refers to the belief that the system is not troublesome or does not require a great effort at the time of use. Perceived ease of use on e-filing means that the taxpayer does not require great effort to be able to understand how to do reporting via efiling tax returns for the service is easy to understand and use. Perceived ease of use will reduce the effort of the taxpayer in learning the intricacies report via e-filing tax returns [10]. If a person feels that the existing system is easy to use, it will use it, so the ease of use of e-filing will affect the attitude of taxpayers to use e-filing. A system used indicates that the system is better known, easier to operate and easier to use by its users.

- H2: there is positive the influence of perceived ease of use to the use of e-filing.

User satisfaction (user satisfaction) has a significant relationship to the intensity of use. User satisfaction will affect the use of e-filing system. If users feel satisfied with the efiling system, the use of the system by the user will be achieved [11]. If the use of the system has the capability to meet the needs of users, the use of the system will potentially be done continuously so that the intensity of use of e-filing system can be increased.

- H3: There is a positive influence user satisfaction towards the use of e-filing.

Perception of the usefulness of the use of e-filing will affect the use of e-filing. The more benefits perceived by the taxpayer from the use of e-filing, the level of use of e-filing will increase. Perceived ease of use will also affect the rate of use of e-filing. The easier it is operated e-filing will affect more frequent e-filing services are used by the taxpayer. User satisfaction will affect the use of e-filing. If the user is satisfied on the e-filing system, the use of the system will potentially be done continuously so that the intensity of use of e-filing system can be increased.

- H4: there is a positive influences perception usefulness, perceived ease of use and user satisfaction together against the use of e-filing.

\section{RESEARCH METHODS}

\section{A. Variables in this Study}

1) Independent variable: Perception of usefulness (X1), is the extent to which a person believes that using a system will improve its performance [12]. In this study the indicators used include developing performance, system benefits, increasing productivity and enhancing effectiveness.

Perception of ease of use (X2), is a level where a person believes that technology is easy to understand [12]. Reveals perceived ease is the degree to which a person believes that the use of a particular system can make the person free from effort. Free from the intended business is that when someone uses the system, he only needs a little time to study the system because the system is simple, uncomplicated, and easy to understand.
So the indicators used are flexibility, easy to understand, easy to use and easy to interact.

User satisfaction (X3) is a feeling of being clean from happy or unhappy in accepting the information system from the overall benefits expected by a person where these feelings result from interactions with information. There are indicators used to measure user satisfaction, namely system efficiency, system effectiveness, satisfaction and pride in using the system.

2) Dependent variables: The use of e-filing (Y) is a process whereby taxpayers use the e-filing system to report SPT online. E-filing was created with the aim of providing benefits and convenience for the Directorate General of Taxes and taxpayers in the SPT reporting.

The variable in this study is the perception of taxpayers in giving opinions about the online tax system. Respondents were asked to rate each item in the questionnaire according to the context of this study with 5 of the Likert scales (1 strongly disagree to 5 strongly agree). The questions are grouped into independent, mediator and dependent variables with a total of 35 questions to the Individual Taxpayer as the respondent of this study. The first part of the questionnaire is the respondent's demographic profile, which will be used to measure respondents' opinions about the online tax system which includes (name, age, gender, length of work). In addition to that the use of e-filing, perceptions of usefulness, perceived ease of use, user satisfaction integrated into this study are observed variables for online tax systems

The research instrument from this study uses a questionnaire adapted from previous research namely which uses e-filing [13] and usage variables that use perception variables for ease of use of online tax systems [14]. The research location for questionnaires is employees who work in the Telecommunications Company in Batam, namely 45 people from Mitra Telkomsel, 25 people from Indosat Partners, and 30 people from XL Partners, so the population is 100 people. The sample used in this study uses the Solving formula and obtained 50 samples. The sampling technique uses the Random Sampling Technique to overcome the clear objectives stated in the questionnaire given. Random Sampling technique is a sampling method where each element that forms a population is given the same opportunity to be selected as a sample. Using a random sampling technique researchers can minimize by choosing the right sampling design [15].

\section{B. Data Collection Technique}

Trials were conducted to improve the validity and reliability of the questions in the questionnaire before the final administration. Data collection techniques used are primary data by distributing questionnaires distributed to employees who work in Telecommunication companies in Batam using questions which are then filled by the respondent. The questions available in the questionnaire are based on the variables you want to study. Data processing techniques in this study use the SPSS program which is used for data testing and processing. 


\section{RESULTS AND DISCUSSION}

Based on the data from Table 1 it can be seen that the respondents are male sex as many as 20 people, while women as many as 30 . With the percentage of women as many as 30 people shows that most of the respondents in this study were women.

TABLE I. CHARACTERISTICS OF RESPONDENTS BY GENDER AND AGE

\begin{tabular}{|c|c|l|l|}
\hline \multicolumn{2}{|c|}{} & Frequency & Percentage \\
\hline \multirow{3}{*}{ Gender } & Male & 20 & $40 \%$ \\
\cline { 2 - 4 } & Female & 30 & $60 \%$ \\
\hline \multirow{3}{*}{ Age } & $\mathbf{1 6 - 2 5}$ years & 31 & $62 \%$ \\
\cline { 2 - 4 } & $\mathbf{2 6 - 3 5}$ years & 18 & $36 \%$ \\
\cline { 2 - 4 } & $\mathbf{3 6 - 4 5}$ years & 1 & $2 \%$ \\
\cline { 2 - 4 } & $\mathbf{> 4 5}$ years & 0 & $0 \%$ \\
\hline
\end{tabular}

Based on the data in Table 1, it can be seen that the respondents aged 16 to 25 years in this study as many as 31 people who dominate in this study, because most of the young age more accustomed in using e-filing services.

TABLE II. LINEAR REGRESSION RESULT

\begin{tabular}{|l|l|l|l|c|c|}
\hline \multicolumn{1}{|c|}{ Model } & $\begin{array}{l}\text { Unstandardized } \\
\text { Coefficients }\end{array}$ & $\begin{array}{l}\text { Standardized } \\
\text { Coefficient }\end{array}$ & R Square & $\mathbf{t}$ & Sig. \\
\cline { 2 - 6 } & \multicolumn{1}{|c}{$\boldsymbol{B}$} & \multicolumn{1}{c}{ Std Error } & Beta & & \\
\hline (Constant) & 6,191 & 1,102 & & 5,616 & 0,000 \\
\hline $\begin{array}{l}\text { Perception } \\
\text { of } \\
\text { usefulness } \\
\text { (PB) }\end{array}$ & 0,073 & 0,023 & 0,412 & 3,135 & 0,003 \\
\hline (Constant) & 4,802 & 2,056 & 0,322 & 2,335 & 0,023 \\
\hline $\begin{array}{l}\text { Perception } \\
\text { of ease of } \\
\text { use (PU) }\end{array}$ & 0,102 & 0,043 & & 2,336 & 0,024 \\
\hline $\begin{array}{l}\text { (Constant) } \\
\text { Tax payer } \\
\text { satisfaction } \\
\text { (TP) }\end{array}$ & 0,023 & 3,638 & 0,074 & 2,345 & 0,023 \\
\hline
\end{tabular}

\section{A. Hypothesis 1}

Based on table 2 result of linear regression above obtained regression equation for hypothesis 1 :

$$
P E=6,191+0,073 P B
$$

This states that if there is no perceptual value of usage then the value of the use of e-filing is 6.191. Value of regression coefficient of perception of utilization equal to 0,073 . It states that each addition of one perceptual value of usefulness then the value of the use of e-filing increased by 0.073 .

Result of $\mathrm{t}$ test for perception variable of usefulness obtained $\mathrm{t}$ count equal to 3,135 with value significance 0,003 . The value of significance is below 0.05 so it can be concluded that $\mathrm{H} 1$ is influential and significant. This means that there is an influence between perceptions of usefulness on the use of e-filing. Based on table 2, it is known that the coefficient of determination is 0.412 . This shows that the practice of human resources in the form of perceptions of usefulness can explain the use of e-filing by $41 \%$ while the remaining $59 \%$ is explained by other variables outside the model.

\section{B. Hypothesis 2}

Based on table 2 above linear regression results obtained by regression equation for hypothesis 2 :

$$
P E=4,802+0,102 P U
$$

Based on the result of linear regression equation above is known constant value equal to 4,802 . This states that if there is no perceptual value of ease of use then the value of e-filing usage of 4.802 . Value of ease of use perception coefficient equal to 0,102 . It states that each addition of one perceptual value of ease of use then the value of the use of e-filing increased by 0.102 .

The result of t test for perception variable of ease of use is obtained $t$ arithmetic equal to 2,355 with significance value 0,023 . The value of significance is below 0.05 so it can be concluded that $\mathrm{H} 2$ is influential and significant. This means that there is an influence between the perceptions of ease of use towards the use of e-filing. Based on table 2, it is known that the coefficient of determination is 0.322 . This shows that the practice of human resources in the form of perceived ease of use can explain the use of e-filing by $32 \%$ while the remaining $68 \%$ is explained by other variables outside the model.

\section{Hypothesis 3}

Based on table 2 above linear regression results obtained regression equation for hypothesis 3 :

$$
P E=8,529+0,023 T P
$$

Based on the result of linear regression equation above known constant value equal to 8,529. It states that if there is no value of user satisfaction then the value of e-filing usage is 8,529 . The value of ease of user regression coefficient is 0,023 . It states that each addition of one user satisfaction score then the value of e-filing usage increases by 0,023 .

Result of $\mathrm{t}$ test for user satisfaction variable obtained $\mathrm{t}$ arithmetic equal to 0,306 with significance value 0,761 . The value of significance is above 0.05 so it can be concluded that $\mathrm{H} 3$ has no effect. This means there is no effect between user satisfactions with e-filing usage. Based on table 2, note that the value of determination coefficient is equal to 0.044 . This indicates that HR practices in the form of user satisfaction can explain the use of e-filing by $44 \%$ while the remaining $56 \%$ is explained by other variables outside the model.

\section{Hypothesis 4}

Based on the result of linear regression equation above is known sig value b y 0,018 . 
The value of significance is below 0.05 so it can be concluded that $\mathrm{H} 1, \mathrm{H} 2, \mathrm{H} 3$ there influence together. This means that there is an influence between perceptions of usability, perceptions of ease of use and user satisfaction with the use of e-filing.

TABLE III. SUMMARY OF THE RESULTS OF THE HYPOTHESIS

\begin{tabular}{|l|l|l|}
\hline \multicolumn{1}{|c|}{ Hypothesis } & Sig. & Information \\
\hline $\begin{array}{l}\text { H1: There is a positive influence on } \\
\text { perceptions of usefulness against the use of } \\
\text { e-filing }\end{array}$ & 0,003 & Supported \\
\hline $\begin{array}{l}\text { H2: There is a positive influence on } \\
\text { perceived ease use of e-filing use }\end{array}$ & 0,023 & Supported \\
\hline $\begin{array}{l}\text { H3: There is a positive influence on user } \\
\text { satisfaction against the use of e-filing }\end{array}$ & 0,761 & Not Supported \\
\hline $\begin{array}{l}\text { H4: There is a positive influence on } \\
\text { perceptions of usefulness, perception of ease } \\
\text { of use and satisfaction users of the use of e- } \\
\text { filing }\end{array}$ & & Supported \\
\hline Source: Data processed by SPSS & \\
\hline
\end{tabular}

\section{E. Discussion of The Results of Variable Analysis}

1) Effect of perceived usefulness of the use of e-filing: Based on the regression test results have shown no positive influence perceptions of the usefulness of the use of efiling had significant results, meaning that the higher the perception of the usefulness of the higher use of e-filing by the taxpayer. From the data obtained on the respondent's answers to the perception of usefulness also shows alignment with the magnitude of the correlation coefficient is dominated by the selection of a positive response, which means that the majority of taxpayers using e-filing felt that the use of e-filing in the SPT provides benefits. Usefulness in question is the extent to which taxpayers believe that the use of e-filing will improve its performance This shows that taxpayers believe and feel the benefits of using e-filing at the time of filing tax returns online. The benefits that make taxpayers wishing to use e-filing in the future or the period of the next tax year. The results support the research results which states that there is a positive and significant influence between perceptions of the usefulness of the use of e-filing [7]. This means that the usefulness of decisive interest of taxpayers to use e-filing in the process of delivering the SPT.

2) Effect of perceived ease of use against use of e-filing: From the results of the analysis carried out showed a positive and significant influence of variables perceived ease of the use of e-filing, meaning that the higher the higher the level ease of use of e-filing by the taxpayer. Ease is meant is that the taxpayer does not find it difficult to use the e-filing at the time of submission of tax returns. Ease of perceived taxpayer in using e-filing because taxpayers are already accustomed to using information systems and technologies while working and it became one of the factors supporting the implementation of e-filing. The results are consistent with research conducted by Mustapha which states that the ease of use significantly affect the use of e-filing [6]. This shows that ease of use is one reason taxpayers want to use e-filing on an ongoing basis.

3) Effect of user satisfaction against use of e-filing: Based on the data analysis showed no significant effect between user satisfaction towards the use of e-filing, meaning that the higher the satisfaction of the taxpayer, the level of use of efiling by the taxpayer has no effect, because taxpayers using efiling is not used for prolonged periods regularly and only used at the end of the year of SPT reporting. From this it can be seen that if the taxpayer is satisfied on the use of e-filing in submitting tax returns taxpayer is not necessarily frequent use of e-filing. The satisfaction arising from the taxpayers feel no benefit in using the e-filing, so that it can be said that the benefits can lead to complacency. The results are consistent with research conducted by Noviandhini which states that there is no significant effect between user satisfaction variable to variable use of e-filing [16]. That is, the satisfaction felt by the taxpayer does not affect the use of e-filing, so that it can be concluded if the taxpayer is satisfied then they will not necessarily use the e-filing.

4) Effect of perceived usefulness, perceived ease of use and user satisfaction against use of e-filing: Based on the data analysis showed no significant effect jointly between perceived usefulness, perceived ease of use and user satisfaction on the use of e-filing. From this it can be seen that if the taxpayer does not often use e-filing which results in overall hypothesis insignificant together. The results of this study are in line with research conducted by Liang [8] which states that there is an influence between the advantages, compatibility and complexity of the online tax system. It can be concluded if taxpayers find it useful, feel the ease and satisfied will use the e-filing their tax return to report the following year.

\section{CONCLUSION}

Based on the result of hypothesis testing about "Effect of Perception of Utilization, Perception of Ease of Use and Satisfaction of Taxpayer to Use of e-filing by Taxpayer" hence can be drawn conclusion as follows:

- There is a positive influence on the perception of the use of e-filing. This means the perception of usability affects the level of e-filing usage. The higher level of perception of usefulness, then the taxpayer Willmore often use e-filing.

- There is a positive perception of ease of e-filing. This means the perception of ease of affecting the rate of use of e-filing. The higher level of perceived ease, then the taxpayer will more often use e-filing.

- No effect of user satisfaction on the use of e-filing. This means that user satisfaction does not affect the level of e-filing usage. The higher the level of user satisfaction, so taxpayers will not necessarily be frequent use of efiling.

- There is an influence between perceptions of usability, ease of perception and user satisfaction with the use of 
e-filing simultaneously. This means user's ease, ease and satisfaction affect the level of e-filing usage.

Suggestions: Based on the results of the discussion of research and conclusion above it can be given suggestions for further researchers are: a) can add other variables that can provide a broader picture regarding the use of e-filing, b) the number of population used in this study is only one company. Subsequent research is expected to increase the number of samples to be used, so it will be closer to the picture of the results more closely to the actual conditions, c) it's expected in subsequent research to use other types of companies as research objects.

\section{REFERENCES}

[1] A. Adeyemi, "Assesing the Effects of Taxation on Nigerian Economic Growth," In Proceedings of 2013 International Conference on Poverty Alleviation Income Redistribution \& Rural Development in Developing Countries, pp. 185, 2013.

[2] R. Egowan, Assesing e Services From a User Perspective: A Study of The Swedish Electronic Tax Declaration, 2011.

[3] A. Parasuraman, "A Conceptual Model of Service Quality and It's Implication for Future Research,” Journal of Marketing, pp. 49, 1985.

[4] G.C. Tjiptono, Service Quality Satisfaction, Yogyakarta, 2007.

[5] W. Tse, Kepuasan Pelanggan, Klaten: Gramedia., 1988.

[6] B. Mustapha, "The Influence of Technology Characteristics Towards an Online Tax System Usage: The Case of Nigerian Self Employed
Taxpayer,” International Journal of Computer Applications, pp. 30-36, 2014.

[7] R. Situmorang, Hubungan Persepsi Kebermanfaatan, Persepsi Kemudahan Penggunaan Terhadap Penggunaan E-Filing, Yogyakarta: Universitas Sanata Dharma 2016.

[8] H.P Liang, Adoption of E-Government Services: An Empirical Study of The Online Tax System in Taiwan, Online Information Review, 2012.

[9] W.C. Chin and P.A. Todd, "On the Use, Usefulness and Ease of Use of Structural Equation Modelling in MIS Research: A Note of Caution," MIS Quarterly, vol. 19, no. 2, pp. 237-46, 1995.

[10] F. Davis, "A Theoretical Extention of The Technology Acceptance Model: Four Longitudinal Field Studies," Management Science, pp. 186-204, 2000.

[11] DeLone and E. McLean, "The DeLone and McLean Model of Information System Success: A Ten Year Update," Journal of MIS, pp. 9-30, 2003.

[12] F. Davis, "Perceived Usefulness, Perceived Ease of Use, and User Acceptance of Information Technology," MIS Quarterly, pp. 319-340, 1989.

[13] I. Ibrahim, Electronic Filing of Personal Income Tax Returns in Malaysia: Determinants and Compliance Costs, Perth: Curtin University, 2013

[14] S. Jonathan, Metode Penelitian Kuantitatif dan Kualitatif, Yogyakarta: Graha Ilmu, 2006.

[15] Sugiyono, Statistika Untuk Penelitian, Bandung: Alfabeta, 2013.

[16] N. Noviandhini, "Pengaruh Persepsi Kebermanfaatan, Persepsi Kemudahan Penggunaan, dan Kepuasan Wajib Pajak Terhadap Penggunaan E-Filing Bagi Wajib Pajak Di Yogyakarta," Nominal, Barometer Riset Akuntansi dan Manajemen, vol. 1, no. 1, pp. 15-22, 2012 